\title{
Faces Of Banlieue In French Rap Song
}

\author{
A.A. Kartika ${ }^{1}$, S.R.Rusdiarti ${ }^{2}$ \\ \{1anastasya.ayudia@gmail.com, ${ }^{2}$ suriella@ui.ac.id\} \\ ${ }^{1,2}$ Universitas Indonesia
}

\begin{abstract}
Banlieue is a suburban area in France which is close to immigrant communities and their descendants. Banlieue has two important roles for their young generations, as a social space and as an expression space. Rap is one of the cultural products of this young people that was born in this social space. This article will show the extent to which young people in banlieue areas are represented in Sadek's song: Banlieue. In this song, the banlieue is not only represented as a space of construction, but more like a multidimensional space that represents the life of the immigrants and their youth in France who never escapes from the various social problems that occur there. Using qualitative methods and the concept of representation, the results of the analysis reveal the other side of the banlieue as a battle arena and dream space for this youth suburban .
\end{abstract}

Keywords : banlieue, immigrant, french rap, social spaces, representation, youth

\section{Introduction}

The French government builds suburban peoples settlements with a very cheap rental price to meet the needs of immigrants residences, which is known as bidonville. This area is very close to poverty, criminality, and various other social problems. Therefore, the French government decided to destroy bidonville and precisely in 1976, the last bidonville in the city of Nice was destroyed. Instead, the government proposed to build a residence for the immigrants in the suburb that known as banlieue. The French government only focuses on building large numbers of residences, but do not think much about social interaction between peoples that living in banlieue.[1]

The majority of banlieue residents are immigrants from Maghrebi and African countries that have low incomes. The differences of historical backgrounds, culture, religion, and races among immigrants and indigenous peoples of France sparked social problems that causes they are both difficult to integrate. According to Goaziou[2] in his book titled Les Banlieues: La culture jeune vient des banlieues, meaning youth culture born from banlieue. The culture of the youth of banlieue are closely related to the lifestyle and cultural products that becomes the characteristic of them. In this case, banlieue has an important role as an interaction space as well as a space of expression for immigrants and youth in France. Rap music is one of the space and medium of expression for them. The main characteristic of rap songs is the use of vocal techniques to speaks in very fast tempo. Before, rap music lacks of positive appreciation from the music lovers because of many negative stigma that often 
associate rap music with the violence, sex and racism. But as time goes by, rap music is growing and becoming one of favorite genres of music among young peoples in France. Rap music appeared in France in 1980s and influenced by American rap music [3]. One of the rapper who is very famous among French youth is Sadek Bourghuiba. He is a TunisianRussian descent that was born in Paris on May 25, 1991. Throughout his career as a rapper, Sadek has released six albums, that are: La legende de Johnny Niuuum (2012), Les frontières du réel (2013), En attendant JNNMJ2- Johnny Niuum ne Meurt Jamais (2015), Johnny Niuuum ne meurt jamais (2015), Roulette Russe (2015), and Nique le Casino (2016). The 'Banlieue', song is one of Sadek's song from his album entitled 'Johnny Niuum ne Meurt Jamais',

There are some previous studies that have discussed rap songs in France. About the history, development, and aesthetics of French rap songs as discussed by Béthune [4], Hammou [5] and Martinez [6]. Likewise some writings on banlieue, violence, and young people discussed by Derville [7], Estébe [8], and Tissot[9]. This article will show the picture of banlieue as a multidimentional, multiethnic, multigenerational social space, through the lyric of Sadek's song: Banlieu. This article will also show a banlieue from different point of view, that is as a space of expression for immigrant and youth in France, and rap music as part of the youth culture in France as well as their way to get out of shackles discrimination.

\section{Research Method}

In this research, will be used qualitative method with content analysis. Content analysis technique is a research technique for produce abjective descriptions to analyze the message of the text and ways to express it, with valid inference and can be researched based on the context[10]. This method is used to analyse the lyrics of the song Banlieue and describes how youth people in banlieue represented through the lyrics of the song with the concept of representation from Stuart Hall. According to Hall [11], the meaning that contained in representation word is to represent or re-presenting something and to stand in, to represent something. Representation can also be interpreted as a concept used in the process of meaning through the sign system. Some peoples that comes from the same culture, they share the same experience, the same culture codes, speak the same language and share the same concepts. It's the same case with rap music as a cultural product, the young peoples in the banlieue shares the same cultural and language code known as la langue de la cite or verlan which is often used in French rap song lyrics. Le verlan is the argot or slang language which is widely used by young peoples in France.[12]

\section{Results And Discussion}

Literally, banlieue can be interpreted as a residential area located on a suburban area. However in this song, banlieue is not only displayed as a space with many buildings but as a social space for multi-ethnic and multigenerational societies that lives here. As explained in the introduction, the word banlieue is always associated with negative matters. The following is a song lyric analysis that shows the negative stereotypes of the banlieue. 


\section{C'est la banlieue \\ C'est la guerre, on a plus de munitions \\ (It's a banlieue) (It's a war, we have more ammunitions)}

These quotes are the first two sentences of song. The word war in the beginning has become a clue that in banlieue will be found a lot of conflict, violence, fighting, and contestation.

\section{La banlieue c'est dangereux}

(banlieue is dangerous)

The word danger in the lyrics has two meanings. On the one hand, banlieue is a dangerous place because it is an area full of conflict and crime. On the other hand, banlieue is dangerous, because it has a lot of potential power that comes from a variety of ethnic, cultural, and local wisdom it has, especially from young people. The word dangereux that is often associated with things that are negative, is used to show the strength and pride of the banlieue community against themselves, their place of residence, and all things related to banlieue, although life in this place can be said far from the word worthy, comfortable and safe. The sentence is repeated more than 10 times in this song. We can feel the meaning and deep emotion from the lyrics of this song. These lyrics are the points important that represents the spirit of people in banlieue to challenge various stereotypes negative attributes attached to them.

\section{J'en ai rien a foutre de vendre des grammes}

(I do not care to sell grams)

Through the lyrics of this song, we can see the banlieue as a real portrait of poverty in France. These conditions forcing them to do everything to get money and finance their families, one of them by selling drugs. The word grammes in the lyrics refer to the unit of measure of weight that is widely used in drugs transaction. It shows the reality of the harshness life of the immigrants in banlieue. For a long time, the banlieue is known as a place for illegal sale transaction (drugs and weapons). The high number of the immigrant descendants who has to drop out (le décrochage scolaire) is one of the main factors of high level of criminality, unemployement, and poverty in the banlieue, especially among the youths. This is what ultimately forms a variety negative stereotypes about young people living in the banlieue, as seen on the this lyrics :

\section{Ils croient qu'on est bête \\ Mais dans nos cerveaux c'est la fibre optique \\ (They believe we are bad people) \\ (But in our brain contains the fiber optics)}

Many people assume that everyone who lives in the banlieue is a bad person, whose life are identical with violence, crime, and so forth. The negative stereotypes has been attached to immigrants and youth living in the banlieue. The use of the word la fibre optique which is very closely related to modern technology, is used to break all the stereotypes and negative views of the immigrants in banlieue. In fact, there is also a tremendous potential, just as well as fiber optics that can transmit light signals very quickly though its size is very small. In addition, the word la fibre optique in the lyrics of this song as well representing the banlieue and its residents that are close to technological developments, as well as connected and open to all developments in a global society. It means, ghettoization does not make them close themselves to any changes and developments happening in the world. 
But in this song there is an interesting thing where there are stereotypes created by the banlieue community themselves associated with their residence, that is:

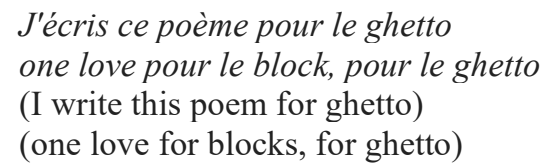

From that lyrics, we can see the love of banlieue society to their place and in this song there is a message from the banlieue community who wants the peace and unity. They want to be accepted as part of French society and escaped from all forms of ghettoisation that has been shackle them all this time. This is in line with Eric Maurin's discussion in his book entitled Le Ghetto Français [13], which reveals social segregation in the banlieue region due to local policies, especially in the field of education. Young people try to boast of their place of residence and get out of the negative stigma attached to it. But until now, it has not been realized.

People who live in banlieue are often underestimated because this area is mostly inhabited by immigrants from lower middle class social who are often associated with various acts of violence, drugs, criminal acts, poverty, and other. The impact of these negative stereotypes is not only felt by some particular people, but everyone who lives in banlieue. As noted earlier, the negative stereotypes attached to people in banlieu have shaped the public opinion that their presence brings only the problems and negative influences to France. One of the social problems that remains the focus of the French Government until now is the issue of discrimination experienced by immigrants living in France. Although they are already administratively registered as French citizens, immigrants and their descendants still have to deal with various discriminatory acts. Childrens of immigrant descendants are often excommunicated and discriminated against by friends at their schools. It makes them tends to be difficult to adapt in the surrounding environment and in the end they will lose the motivation to go to school. The real impact from this problem felt by young people is the difficulty in finding a job, as seen in the following song lyrics:

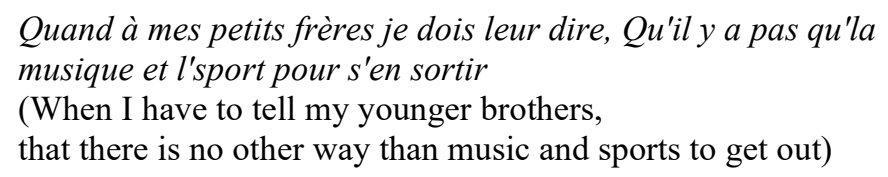

The meaning of the word sortir which means go out on the lyrics of this song, is free from all acts of discrimination, racism, and ghettoization. From these lyrics, we can see the desperation and anxiety of the young people about their future. They realize that they lack of competence and educational background to compete with other young people who live in comfort and have a higher educational background than they are, especially in terms of work. And this situation causes social despair (la désespérance sociale) and collective crisis of youth (la crise d'adolescence collective). One of the attitudes of youths in France to face this unfavorable social situation is to gather with the community and the gang. The existence of these gangs is quite disturbing the surrounding community because they are often involved in fights between the banlieue citizens and the police due to various acts of crime and violence. As a result, their space became very limited because it is always supervised by the police.

In the souls of suburban youths, deeply embedded in fear and despair of their future. Suburban youths in France realize that the only way to change their destiny for the better and to raise their social class is to become a famous musician or professional athlete, and it has 
been embedded in the banlieue since they were children. Rap music is one of the most common way of youths to escape from discrimination, racism and ghettoization. As time goes by, rap music is not only regarded as a means of expression and cultural products of youths in banlieue, but a dream that can bring a great change to their lives. This is evidenced by the large number of youths who decided to be a rapper in France. Through this song, they want to prove that suburban youths can also succeed in their own way.

\section{$J$ 'remercie Mohamed He, Malamine Koné, BB, et Bernard Tapie Joue comme Zinédine Zidane \\ (I thank Mohamed Dia, Malamine Koné, BB, and Bernard Tapie.) \\ (Playing like Zinédine Zidane)}

The lyrics above show the banlieue's pride and gratitude towards all successful immigrants in their respective fields, such as: Mohamed Dia, Malamine Koné, BB, and Bernard Tapie, who have paved the way for suburban people to achieve their dreams, both in the arts and sports. The famous figures whose names are mentioned in this song lyrics have been represented the people who live in banlieue. As part of the immigrant community they have represented (to stand in) suburban youth in France and the whole society of banlieue who are often being the victims of various discriminatory acts. Through these figures, they want to show that negative stereotypes about immigrants in France, often associated with crime, violence and terrorism, are not always true. It's an irony, in which the attitude of native French people who previously did not like the immigrants can change completely when they are successful and famous in their respective fields. In other words, they can accept an immigrant as part of them not because of who they are but because of the talent and popularity that can bring benefits to them and their country. For example France is increasingly recognized in the world of football and widely visited by world tourists, thanks to the talent and popularity of a world renowned French footballer, such as Zinédine Zidane who in fact comes from immigrants.

Banlieue in this song is packaged and presented in different ways, not only as a space filled with social problems, but also a space of expression and dreams for suburban youths in France. We can see that their incompetence in education does not necessarily discourage them and give up on the situation. This is evidenced by the many successful banlieue peoples in their respective fields (music and sport), as well as succeeding in raising their social class and being accepted as part of French society.

Les grands artistes viennent de banlieue, Les hommes d'affaires viennent de banlieue, Les grands sportifs viennent de banlieue

(Great artists come from banlieue, entrepreneurs come from banlieue, big athletes come from banlieue)

Through this song, they also want to show that the harsh lives of youths in banlieue who are far from comfortable and safe, are precious experiences and life lessons for them. Discrimination, racism, poverty, violence, drugs, and other things related to crime have become part of their lives. These are all valuable lessons in their lives that they would never get in any educational institution. It can not be denied that it is the trigger of various social problems in banlieue, one of which is the high number of criminals among the banlieue youths. But on the other hand, all those problems have made them a strong figure and it is a race for them to dare to dream and fight until they can reach all of their dreams and be in the top position. The harshness of life in the banlieue is not an obstacle for them to continue working. 
Sadek's Banlieue song presents a different rap face when compared to works by Suprême NTM, a French hip-hop group popular in the early 1990s. The public and some social researchers such as Djavadzadeh[14], and Martinez [6], refer to NTM as a hardcore rap group. They are called hardcore because they often use provocative words and explicitly insult the officials of the French Government, especially the police who are considered to be doing a lot of repression. Some NTM works are also subject to censorship, for promoting bullets and guns against the police. Sadek's Banlieue has the same soul as the work of Kery James, one of the French rapper, entitled Banlieusards. Banlieusards also invited young people in banlieue to be optimistic about the future. R. Éreau in his article stated that the rap song of Kery James is a platform to openly testify to the French public about the situation and conditions of young people in the banlieu [15]. While Scooter Pégram stated in his article that the song Banlieusards emphasized the need for mission and ambition for young people in banlieu to be able to compete with the majority of French people who are luckier and have better facilities.[16] If Kery James in his song invites young people to become positive resistance entrepreneurs, then the results of the content study of this article show that Sadek firmly stated that there are only two main ways to get out of bad conditions in the banlieue, namely by art, and sports. Sadek also touched on the importance of equal education for young people in the banlieue.

\section{Conclusion}

The lyrics of Banlieue from Sadek, has represented the culture of young people of France living in banlieue areas, who are always confronted with social problems, which deal with negative stereotypes, acts of discrimination, racism and ghettoisation in society. We can see that the song was created to reinforce the stereotype attached to people of banlieue, while providing a new face for suburban youths. Through the lyrics of this song, they acknowledge that banlieue has a negative side but on the other hand we can also see the positive side of banlieue that is often overlooked, and that the harshness of life faced by people in banlieue becomes the motivation for them to be successfull, and become a strong figure. We can also see the spirit of youth to continue to work hard and rise from adversity and be success in their respective fields. The work and accomplishments of youths in the field of music and sport have proved that they also have tremendous potential that has brought the name of France to the international scene. In this song, banlieue is presented as a multidimensional space, which is social space, dream space, and battle space for the youth people. Banlieue as a space of expression has an important role in their lives. In this social space, youths can freely channel their expressions and creativity through work. In the midst of various acts of discrimination, banlieue present as a dream space as well as a battle space for them to continue to fight for their life and dreams. Through the lyrics of this song, they also want to break the negative stigma that has been attached to the people of banlieue and their place of residence. We can say that this song is an effective way to convey social criticism of all forms of injustice and social problems faced by people in banlieue. This song is a song full of social themes, the content of this song is very relevant to all the problems faced by people in banlieue until today. 


\section{References}

[1] D. Garbin and G. Millington, "Territorial Stigma and the Politics of Resistance in a Parisian Banlieue: La Courneuve and Beyond," Urban Stud., 2012.

[2] V. Le Goaziou and C. Rojzman, Les banlieues. Ed. du Cavalier bleu, 2006.

[3] A. J. M. Prévos, "The Evolution of French Rap Music and Hip Hop Culture in the 1980s and 1990s," French Rev., 1996.

[4] C. Béthune, Pour une esthétique du rap. Klincksieck, 2004.

[5] K. Hammou, "Des raps en français au « rap français »," Hist. Mes., 2009.

[6] I. Marc Martínez, "Intermediality, rewriting histories, and identities in french rap," $C L C W e b$ Comparative Literature and Culture. 2011.

[7] G. Derville, "La stigmatisation des «jeunes de banlieue»," Commun. langages, 1997.

[8] P. Estèbe, "Maurin, Éric. 2004. Le ghetto français. Enquête sur le séparatisme social. Paris, éditions du Seuil, coll. « La République des idées ».," Lien Soc. Polit., 2012.

[9] S. Tissot, "Les sociologues et la banlieue: Construction savante du problème des «quartiers sensibles »," Geneses, 2005.

[10] H. F. Hsieh and S. E. Shannon, "Three approaches to qualitative content analysis," Qual. Health Res., vol. 15, no. 9, pp. 1277-1288, Nov. 2005.

[11] S. Hall, J. Evans, and S. Nixon, Representation. .

[12] C. Baker, "Languages of Global Hip Hop," IASPM@Journal, 2013.

[13] H. Paris, "Éric Maurin, Le ghetto français," Rev. des Polit. Soc. Fam., vol. 81, no. 1, pp. 103-104, 2005.

[14] K. Djavadzadeh, "Trouble dans le gangsta-rap: quand des rappeuses s'approprient une esthétique masculine," Genre, Sex. société, 2015.

[15] F. Plassard, "Les banlieues en France, territoires et sociétés," Géocarrefour, 2000.

[16] S. Pégram, "Not condemned to fail: Examples of 'rapped' resistance and cultural uplift in French hip-hop," J. Poet. Ther., 2011. 